\title{
ANALYSIS OF THE ROLE OF PARENTS AND THE COMMUNITY IN VALUE EDUCATION AND CITIZENSHIP EDUCATION
}

\author{
Rahmat Nurul Walidaini, Marzuki
}

This article aims to describe the extent to which parents and society participate in the value education of civic education. Using qualitative methods of holistic case study type, this research was conducted in two villages, which became the research locus, namely Tawali and Banta, Wera Subdistrict, Bima Regency, with the subjects, among others, parents and community leaders; Youth, as well; Religion. Collecting data using interview and documentation techniques. Triangulation techniques in this study are used to test the validity of any data and information that the researchers get about cases that are the focus of research by verifying data and information from the same source with different techniques. The researchers performed the data analysis using source triangulation techniques to obtain the same data from different sources. Data is then presented in a narrative in the form of arguments with specific premises about phenomena and facts, which are the focus of research to reach general conclusions, thus inductive. The results obtained reveal that the family and community environment is proven to be a variable that influences children's efforts to form and develop values, both those they get from their parents and those from the surrounding community

Keywords: the role of parents and society, value education, civic education

\section{How to cite:}

Nurul Walidaini, R., Marzuki (2021). Analysis of the role of parents and the community in value education and citizenship education. ScienceRise: Pedagogical Education, 3 (42), 22-26. doi: http://doi.org/10.15587/2519-4984.2021.226040

(C) The Author(s) 2021

This is an open access article under the Creative Commons CC BY license

\section{Introduction}

Various progressivities, produced by technology and science, apart from offering gradual convenience, also have an impact on the patterns and behavior of human life, especially the Indonesian generation today, which is very significant dominated by the pragmatic values of western life philosophy, starting from the way of thinking, behavior and expression to a certain stage it touches the value order of life in society, which at least describes the alienation of humans from their humanity, especially in the structure of modern society who are not wise and less selective as consumers, making them enter and blend into a new confusing condition, namely "hyperreality". This condition is characterized by a mixture of falsehood and authenticity, the past mingles with the present, facts are confused with fabrications and lies are mixed with truth [1]. State who according Febriana [2] makes people modern become redundant in the pattern of consuming something is not clear essence.

The intuitive morality model approach to examining the influence of media on cognitive mechanisms by describing how media content can influence the strength of moral intuisions (instincts related to morality that has developed in humans through an evolutionary process) has been used by Tamborini et al [3] to describe a reciprocal process, where media representations and audience moral instincts continue to influence one another. This at least proves that there is a positive rather than negative influence from media content, consumed by the younger generation.

\section{Literary review}

The existence of society, especially the younger generation, consuming various information products and their contents, has also unwittingly had a negative impact on the development of the generation with the circulation of a number of content in the media, as stated by Cholil [4], hate speech, pornography, racism, sexual harassment, as well as other crimes and violence. All of these are said to be factors that can affect the psychological development of generations to a serious stage, namely the loss of values and characters, such as culture, religion, no longer ignoring the norms and values, prevailing in society, such as respect for others, parents and so on. So education as an effort to humanize humans, according to Bahri [5], not only emphasizes the development of hard skills but also emphasizes the development of soft skills (etika dan moral).

The development of soft skills is intended as an effort to foster mentality by instilling goodness values, including politeness, ethics and morals, which are then implemented in the attitudes and behavior of everyday life as a form of ethical intelligence of a good citizen. This presupposes that the synergy of stakeholders is not only the task of the teacher and the school environment as the domain of formal education, but becomes a join necessity, which also involves the family environment (informal) and the community environment (non-formal) as an internalization agenda, the value for generations, carried out in a cooperative scheme to build an ideal society according to the ideals of the Indonesian nation.

Various schools around the world instead of in Indonesia and especially in Wera Subdistrict, Bima Regency, have used various methods to introduce moral goodness to their students. In an effort to turn their youth into moral citizens, schools in Queensland Australia, for example in the mid to late 20th century, have adopted 
different ways of imparting morale in their students. One of them is, as stated by Carden [6], that Citizenship and Moral Education there integrate literary aesthetic and heroic values, found in poetry, historical stories and their own culture, into Citizenship Education and moral education. This is a relevant way in their opinion to instill moral values in the younger generation, especially students in Queensland, one of the reasons, according to Birx [7], because stories are the means, through which important cultural, historical and moral information is always be delivered; and one of the reasons why the moral literature explicitly dislikes the reader, according to Brown [8], because that literature does not have good literary value.

Citizenship Education in Indonesia has a different approach with an emphasis on moral cultivation practices in general in the area of formal education. Apart from Civics, morals are usually introduced through value education and religious education. Value education is important in the Indonesian context as a Pancasila State, according to Zakiyah \& Rusdiana [9], because in essence it demands education in values because its characteristic is in the commitment to values, contained in Pancasila. In order to form good young citizens in the Indonesian context, especially in terms of the role of inculcating, moral values towards the younger generation are not only a school task because, according to Wening [10], Value Education can also be carried out in the family and community environment, which includes parents, peers as well as the mass media. In that context, a much stronger role for family and community organizations than just for teachers as well recommended by Mclaughlin [11]. The implicit of these opinions illustrates that moral values can not only be taught and learned in schools only, but also in the family environment and the surrounding community, namely the family or people elderly and people in general.

Likewise with value education, in civic education, the contribution of the family and community environment is needed in a joint effort to build the character and moral of the generation and to foster a sense of love and spirit to defend the state or nationalism, because civic education is also sometimes interpreted as moral and character education. This is then reinforced by a thesis from Arthur, Davies, \& Hahn [12], which states that civic education is also sometimes the domain of moral education, among which the aim is to learn to live with other people. This opinion can be affirmed as a truth if it refers to what is the goal of civic education, according to Kerr, Schulz, Ainlay et al [13], which is an effort to prepare young people for their roles and responsibilities as citizens. Because in the end a democratic country must rely on the knowledge, skills and virtues of its citizens [14]. Skills and knowledge are related to the technical intelligence of being citizens while virtue includes character, ethics, and morals as aspects of the ethical intelligence of citizens.

Among other things, what is mandated as well as an important part of the preamble of the 1945 Constitution of the Republic of Indonesia is educating the life of the nation. This proposition is one of the reasons for writing this article, which focuses on discussing the scope and role of the family environment, as well as society in value education as well as civic education to illustrate the involvement of two external sectors besides formal educational institutions, such as schools, in cooperative efforts, educating the nation's life that has started. By building the character of the generation as well as young citizens, where in time they will act as agents of change, determining the direction of future changes in Indonesia, of course based on Pancasila as the basis of the State as well as dynamic Leitsar (view of life), guiding the direction of struggle and expected change.

\section{The aim and objectives of the study}

The aim of this study was to analyze the role of parents and community in value education and civil education.

To achieve this aim, the following objectives are accomplished:

- Determine the role of the family and society in children's education

- Justify (based on field evidence) the role of parents in children's efforts to form and develop in value education and citizenship education

- Justify (based on field evidence) the role of community in children's efforts to form and develop in value education and citizenship education

\section{Materials and methods}

This study uses a qualitative method type of holistic case study, conducted in two villages, which became the research locus, namely Tawali and Banta, Wera District, Bima Regency, with subjects including parents, community leaders; Youth, as well; Religious leaders. Data collection using observation and interview techniques. Technique triangulation in this study is used to test the validity of any data and information that the researcher gets about the case that is the focus of the research with verified data and information from the same source with different techniques. The researchers performed the data analysis using source triangulation techniques to obtain the same data from different sources. The data is then presented in a narrative manner in the form of argumentation and inductive conclusion.

\section{Results and discussion}

The family is a small group or community that is related to and becomes part of a community, usually consisting of father and mother as parents and children in it. The family is also a place or space for socialization and ongoing education process to take place, which is marked by new members from the community, getting education to know, understand, obey, and respect the prevailing rules and values. According to Rakhmawati [15], an educational process occurs in the family in the sense of maturing from a helpless individual to a personal candidate who knows basic knowledge, social norms, values, and social ethics. Therefore, in the context of education, the family is also an educational institution for individuals where the process brings it into an increasingly independent atmosphere. The point where parents bring, introduce, teach, and instill everything about the value of goodness, including moral and social behavior in their children, is a series of patterns, known as parenting and has an impact on the child's development. This is based on the opinion of Holden [16] that the context of parent- 
ing has an impact on the trajectory of children's development, including social and anti-social behavior.

Value education in the context of the family environment is a part that is naturally integrated as part of the goal of parenting, which is the moral obligation of parents to their children, shapes character and teaches positive values, such as responsibility, politeness, honesty, tolerance, discipline, hard work and more. According to Aitken [17] in this case, parents feel a strong moral obligation to pass on positive values to their children as an accepted part of good parenting. Meanwhile, according to Millar \& Ridge [18], not providing education or good care for their children is considered a failure of parents. Parenting efforts by parents, of course, can be said as a measure of how the role of parents is very influential in the good growth and development of their children, including in the effort to internalize values as the goal of value education. One of them is so that children have good and effective self-control and regulation skills [19].

According to Valentine, Jayne, \& Gould [20], school plays a role in introducing and teaching values or character as a subject, however, parental authority should not be damaged by schools in relation to character building. The statement confirms that there is an authority from parents to educate, introduce, and instill values and shape the character of their children as a form of parental responsibility towards children. Thomson \& Siegel [21] state that with regard to commitment to a person's good or bad character, it is very much influenced by the interaction of family, civil society, and classrooms. So the family environment does have an important role in determining the character of their children by teaching and internalizing good values, such as social behavior, as well as moral sensitivity to children.

With regard to value and character education, there are several roles from various sectors that can be classified based on their scope, such as the family environment (parents and relatives), society (peers and the surrounding environment), and school (educators as well as peers). These three sectors have their respective capacities and role limitations, but are closely related to each other, it is necessary to have awareness of actors, representing each sector by sharing knowledge and ideas about how they can maximize their role in developing and helping to optimize value education, for example teachers as actors in formal education, need to build relationships with parents in particular, as well as society in general or vice versa. According to Egbert \& Roe [22] teachers need to identify and communicate student knowledge at home to strengthen the relationship between school and parents, as well as schools and the community, in order to enable students to become more involved in learning and form individual character as well as student social behavior.

The role of parents does have a significant influence on the understanding of the values, growth, and character development of their children in their interactions with parents and this influence occurs in interaction patterns both as an effort to exemplify positive behavior and to exchange understanding, knowledge of values and norms, such as those stated by Liebermen [23] that humans as social animals continue to interact with one another to exchange physical objects, intangible services, and information, during which humans influence each other directly and indirectly when they communicate feelings, information, following opinions. This is a pattern that works naturally as an ability to create an impact and lead to changes in behavior either in others or to themselves [24].

Efforts to build the character of the nation (membangun karakter bangsa) to make citizens with character, dignity, and active in the process of national and state life is part of the common goal of "educating the nation's life" as well as being the goal of the procurement and implementation of Pancasila and Citizenship Education as subjects, learning to internalize values to students as a generation as well as young citizens. In Indonesia, Pancasila and Citizenship Education, according to Liem \& McInerney [25], is considered as part of the citizen enculturation process of the national value and identity system, known as Pancasila, before PPKn was changed to "Citizenship education". As a science, civic education discusses the relationship between humans and humans in organized associations (social, economic, political organizations) and individuals with the state.

Citizenship education is essentially education that leads to the formation of good and responsible citizens based on the values and the basis of the state Pancasila, or in other words, civic education is Pancasila education in practice. Conceptually epistemologically, civic education is seen as an integrated knowledge system with Pancasila. According to Winataputra [26], Civics directs attention to morals in the hope that it can be realized in everyday life. Citizenship education is not only seen as a means to shape future citizens, but must also promote the values of fairness, mutual respect, justice, autonomy, integrity, honesty and generosity [27]. Based on this opinion, Civics is also the domain of value and character education, which is oriented to how to introduce, cultivate, and develop these values in the person of each student as a young citizen.

Citizenship education is a field of scientific studies, curricular programs, and multidimensional sociocultural activities, this multidimensional nature, which then causes Civics to be treated as value and moral education, social education, national education, political education, legal education and human rights as well as democratic education. Efforts to institutionalize Citizenship Education are not only limited to educational institutions or schools. The role of family and society in citizenship education is also possible based on the opinion of Liem \& Chua [28] that a multidimensional-multilevel approach is needed for the framework of ecological development of civic education, and that includes traditional citizenship knowledge with community participation, goal orientation and future, family influence, as well as perceptions of utility and civil capital. This approach presupposes the existence of a relationship and the influence of interaction and communication in the environment, both family and community, for the development of knowledge of citizenship.

This opinion is then reinforced by the statement by Neufeld \& Davis [29] that parents should be given as much freedom as possible to raise their children according to their respective comprehensive doctrines, such as belief systems and values, including religion, and chil- 
dren must learn to interact with citizens of other countries in the social order as a complete concept and skills, needed to become future citizens. This opinion clearly explains that to become a citizen requires a concept and skills for everyone, which can be obtained in the family environment through doctrine and internalization of values by parents as well as interactions between individuals and communities, such as community groups in the surrounding environment. It is at this point that the role of the family and society in civic education can be identified.

According to Cogan \& Derricott [30], Citizens are members of a society, citizenship is a set of characteristics, contained in individuals as well as groups that are labeled as citizens, while civic education is the contribution of education to developing the characteristics of being citizens. The ultimate goal of citizenship education, especially in Indonesia, is the creation of smart and good citizens with the characteristics of the growth and development of social sensitivity, presumption, criticism and creativity in the context of an orderly, peaceful and creative life of the nation and state, as a reflection and embodiment of values, norms, and the moral of Pancasila. According to Tolib \& Nuryadi [31], individuals as family members, students in schools, community members, citizens and mankind must be critical and behave well and creatively according to shared values. So being a citizen, one must act and behave in accordance with the values and norms of citizenship in one country as a form of intelligence both technically and ethically.

Education Curriculum nationality by Ainley, Schulz, \& Friedman [32] dominated formal and tended to focus on creating good citizens (warga negara yang baik), the common good (kebaikan bersama), as well as moral education (pendidikan moral), as well aspects of the values associated. Meanwhile, the scope of Civics, according to Kennedy \& Brunold [33], in the core curriculum must go beyond national boundaries but without limiting and eliminating regional authority to seek goals in global citizenship competence. This explanation emphasizes that the position of civic education as a subject must create citizens who have the ability to understand and interact globally without neglecting the values in their own citizenship culture and in this effort the role of parents and society is very much needed.

The role of parents and the community became very pronounced in view of the influence of each on the process of shaping the character of a good citizen (warga negara yang baik). In the family environment, for example, emotional closeness in the pattern of parents, taking care of their children, is an effective way to build ideal citizen character in children, even families have greater authority than the school environment, this is based on the statement of Thompson \& Mazer [34] that to find out the success of students, it is more likely to ask the parents of students themselves because the relationship between children and parents is closer than the relationship between teacher and student. Even the ability to think and speak of individuals is a char- acteristic, instilled by parents from the start in the family environment [35]. The closeness between children and parents is also a supporting indicator of the success of parenting in instilling values and shaping the character of their children both as individuals with complex personalities in a positive sense and as citizens with knowledge (civic knowledge), skills (civic skills), and personality (civic disposition) as a good citizen (good citizen).

The community environment also very clearly has a major influence on the success of bringing up aesthetic and ethical values for the formation of a person's character, society as a center of education after family and school has different functions with unpredictable scope and boundaries due to the diversity of life forms and types, culture in that society. According to Subianto [36], education in families and schools cannot be separated from socio-cultural values that are upheld by all levels of society, because wherever a society must have its own character and values as a distinctive norm that is different from other societies. So, parents and society play a very important role in efforts to optimize value education and civic education.

\section{Conclusion}

The ideal of building a generation that has intelligence both conceptually (knowledge and emotion) and praxis (attitudes and behavior),] has Pancasila and democratic characteristics; has noble character; will not be able to be realized if it only relies on the efforts of schools as incubators that will produce intellectual generations, the nation's successor with only knowledge, especially in the world conditions that are rapidly changing and affecting all aspects of life as it is today, then there is also a need for the role and awareness of the family and society in terms of providing education about social and moral behavior to their children as values and character (nilai dan karakter) of citizens who have full awareness of their responsibilities as agents of change with ethical and technical consequences that they will determine the direction of change in a nation as big as Indonesia. The conclusions based on the findings are;

1. The pattern of interaction between children and family and with the community shows that there are children's efforts to model positive behavior and to exchange understandings, knowledge, values and norms.

2 . The role of parents does have a significant effect on understanding the values, growth, and character development of children in their interactions with parents and this influence occurs in interaction patterns both as an effort to model positive behavior and to exchange understandings and knowledge, values and norms.

3. Likewise for society, evidence in the field shows that the role of society does have a significant influence in children's efforts to form and develop values and citizenship education.

\section{Reference}

1. Baudrillad, J. (1983). Simulations. Columbia Uniersity New York City, 1-124.

2. Febriana, M. (2017). Hiperrealitas "endorse" dalam instagram studi fenomenologi tentang dampak media sosial di kalangan mahasiswa Universitas Sebelas Maret. Jurnal Analisa Sosiologi, 6 (2), 18-29. doi: http://doi.org/10.20961/jas.v6i2.18098

3. Tamborini, R., Eden, A., Bowman, N. D., Grizzard, M., Weber, R., Lewis, R. J. (2013). Predicting Media Appeal From Instinctive Moral Values. Mass Communication and Society, 16(3), 325-346. doi: http://doi.org/10.1080/15205436.2012.703285

4. Fikri, A. (2019). Pengaruh Globalisasi dan Era Disrupsi terhadap Pendidikan dan Nilai-Nilai Keislaman. Sukma: Jurnal Pendidikan, 3 (1), 117-136. doi: http://doi.org/10.32533/03106.2019 
5. Bahri, S. (2015). Implementasi Pendidikan Karakter dalam Mengatasi Krisis Moral di Sekolah. Ta'allum: Jurnal Pendidikan Islam, 3 (1), 57-76. doi: http://doi.org/10.21274/taalum.2015.3.1.57-76

6. Carden, C. (2018). Reading to the soul: narrative imagery and moral education in early to mid-twentieth-century Queensland. History of Education, 47 (2), 269-284. doi: http://doi.org/10.1080/0046760x.2017.1420242

7. Birx, H. J. (2010). 21st Century. Sage publiications Ltd, 21. doi: http://doi.org/10.4135/9781412979283

8. Brown, R. M. (2015). The nathan syndrome : stories with a moral intention. Religion \& Literature, 16 (1), 49-59.

9. Zakiyah, Y, Q \& Rusdiana, H. A. (20014). Pendidikan nilai: Kajian teori dan praktik di sekolah. Pustaka Setia, 1-26.

10. Wening, S. (2012). Pembentukan karakter bangsa melalui pendidikan nilai. Jurnal Pendidikan Karakter, 2(1), 55-66.

11. McLaughlin, T. H. (1992). Citizenship, Diversity and Education: a philosophical perspective. Journal of Moral Education, 21 (3), 235-250. doi: http://doi.org/10.1080/0305724920210307

12. Crick, B.; Arthur, C. J., Davies, I., Hahn, C. (Eds.) (2010). Democracy. The SAGE handbook of education for citizenship and democracy democracy. Sage Publiications, 13-19. doi: http://doi.org/10.4135/9781849200486.n2

13. Kerr, D. Schulz, W. Ainlay, J. Fraillon, J, B. L. (2010). ICCS 2009 International Report : Civic knowledge, attitudes, and engagement among lower- secondary school students in 38 countries. Available at: https://eric.ed.gov/?id=ED520018

14. Setiawan, J. A., Suparno, S., Sahabuddin, C., Tasrif, T., Ramadhan, S. (2020). The Role of Parents on the Character Education of Kindergarten Children Aged 5-6 Years in Bima. Universal Journal of Educational Research, 8 (3), 779-784. doi: http://doi.org/ 10.13189/ujer.2020.080307

15. Rakhmawati, I. (2015). Peran keluarga dalam pengasuhan anak. Jurnal Bimbingan Konseling Islam, 6 (1), 1-18.

16. Holden, G, W. (2014). Parenting: A dynamic perspective. Sage publication. doi: http://doi.org/10.4135/9781452204000

17. Aitken, S. C. (2000). Fathering and faltering: "Sorry , but you don't have the necessary accoutrements". Enviroment and Planing, 32, 581-598. doi: http://doi.org/10.1068/a3236

18. Millar, J., Ridge, T. (2013). Lone mothers and paid work: the "family-work project." International Review of Sociology, 23 (3), 564-577. doi: http://doi.org/10.1080/03906701.2013.856161

19. Ramadhan, S., Nasran, S. A., Utomo, H. B., Musyadad, F., Ishak, S. (2019). The implementation of generalisability theory on physics teachers' competency assessment instruments development. International Journal of Scientific and Technology Research, $8(7), 333-337$.

20. Valentine, G., Jayne, M., Gould, M. (2012). Do as I Say, Not as I Do: The Affective Space of Family Life and the Generational Transmission of Drinking Cultures. Environment and Planning A: Economy and Space, 44 (4), 776-792. doi: http://doi.org/10.1068/a4446

21. Thomson, A. L., Siegel, J. T. (2013). A moral act, elevation, and prosocial behavior: Moderators of morality. The Journal of Positive Psychology, 8 (1), 50-64. doi: http://doi.org/10.1080/17439760.2012.754926

22. Egbert, J., Roe, M. F. (2020). The power of why: connecting curriculum to students' lives. Childhood Education, 90 (4),

251-258. http://doi.org/10.1080/00094056.2014.933665

23. Matthew D. Liebermen. (2013). Social: Why our brains are wired to connect. Oxford University Press, 374.

24. Wihardjo, R. S. D., Nurani, Y., \& Ramadhan, S. (2020). The Comparison between the Effectiveness of Guided Discovery Model and Inquiry Model for Early Childhood Education Students. International Journal of Innovation, Creativity and Change, 11 (3), 409-418.

25. Liem, G. A. D., MCINerney, D. M. M. C. I. (2011). Indonesian students and their citizenship- related attributes: implications for instructional strategies and pedagogical practices in civic education. Citizenship Pedagogies in Asia and the Pasific, 149-173. doi: http://doi.org/10.1007/978-94-007-0744-3 8

26. Winataputra, U. S. (2014). Diskursus aktual tentang paradigma kewarganegaraan (PKn) dalam konteks kurikulum 2013. Jurnal PPKn, 2 (1).

27. Wihardjo, R. S. D., Pitri, F., Hasanah, U., Nurani, Y., Ramadhan, S. (2020). Social Behavior of Social Prone Women Related to Norms, Ethics and Environmental Aesthetics in Prumpung. International Journal of Psychosocial Rehabilitation, 24 (8).

28. Liem, G. A. D., Chua, B. L. (2013). An expectancy-value perspective of civic education motivation, learning and desirable outcomes. Educational Psychology, 33 (3), 283-313. doi: http://doi.org/10.1080/01443410.2013.776934

29. Neufeld, B., Davis, G. (2010). Civic Respect, Civic Education, and the Family. Educational Philosophy and Theory, 42

(1), 94-111. doi: http://doi.org/10.1111/j.1469-5812.2008.00506.x

30. Cogan, J. J., Derricott, R. (1998). Citizenship for the 21 st century: an international perspective on education. Choice Reviews Online, 36 (3), 36-1701. doi: http://doi.org/10.5860/choice.36-1701

31. Nuryadi, T. (2017). Pendidikan pancasila dan kewarganegaraan. Jakarta: Pusat kurikulum dan perbukuan, 20-21.

32. Ainley, J., Schulz, W., Friedman, T. (2009). ICCS 2009 Encyclopedia Approaches to civic and citizenship education. Available at: https://research.acer.edu.au/civics/20

33. Kennedy, K. J., Brunold, A. (Eds.) (2015). Regional contexts and citizenship educational in Asia and Europe. Routledge, 200. doi: http://doi.org/10.4324/9781315694795

34. Thompson, B., Mazer, J. P. (2012). Development of the Parental Academic Support Scale: Frequency, Importance, and Modes of Communication. Communication Education, 61 (2), 131-160. doi: http://doi.org/10.1080/03634523.2012.657207

35. Shaleh, S., Zamroni, Z., Mukminan, M., Ashadi, A., Sudrajat, A., Supaat, S. et. al. Mapping the Threat of Radicalism Symptoms among Upper-Secondary Students: A Mix Methode Approach. International Journal of Advanced Science and Technology, 29 (4), 3055-3068

36. Subianto, J. (2013). Peran keluarga, sekolah, dan masyarakat dalam pembentukan karakter berkualitas. Edukasia: Jurnal Penelitian Pendidikan Islam, 8 (2), 331-354. doi: http://doi.org/10.21043/edukasia.v8i2.757

Received date 12.04.2021

Accepted date 18.05.2021

Published date 31.05.2021

Rahmat Nurul Walidaini, Pancasila and Citizenship Education Postgraduate Program, Faculty of Social Sciences, Yogyakarta State University Jl. Colombo Yogyakarta No.1, Karang Malang, Caturtunggal, Kec. Depok, Kabupaten Sleman, Daerah Istimewa Yogyakarta 55281, Indonesia,

E-mail: rnwalidaini0883@gmail.com

Marzuki, Lecturer, Pancasila and Citizenship Education Postgraduate Program, Faculty of Social Sciences, Yogyakarta State University, Jl. Colombo Yogyakarta No.1, Karang Malang, Caturtunggal, Kec. Depok, Kabupaten Sleman, Daerah Istimewa Yogyakarta 55281, Indonesia

E-mail: Marzuki@uny.ac.id 